\section{John Dalton}

Some Unpublished Letters of Personal and Scientific Interest, with additional Information about his Colour-Vision and Atomic Theories. By Dr. E. M. Brockbank. (Publications of the University of Manchester, No. 287.) Pp. $\mathrm{ii}+62+5$ plates. (Manchester : Manchester University Press, 1944.) Cloth, 7s. $6 d$. net; boards, $7 s$. net.

R. BROCKBANK'S modest booklet, dated on the centenary of Dalton's death, does not bring forward any new material of primary importance bearing upon the philosopher's life and work; nevertheless, it will be welcomed by all who are interested in Daltoniana. It contains notes on Dalton's family history, on the Kendal and Manchester periods, on his appreciation of female society, and on his relationships with the Society of Friends and with Peter Clare, together with nine hitherto unpublished letters. There are also short chapters on colour-vision defects and the genesis of the atomic theory. It is revealing that Dalton found Boyle's style "so tedious and verbose" in his chemical tracts "that one cannot reap the full advantage from them, except they were condensed and digested a little better" ; at the same time $(1790)$ he regarded Boerhaave's "Elementa Chemiae", published in 1732, as "a capital" treatise, and approved also of the "essays of the present Bishop of Llandaff"' (Richard Watson). Among other interesting details we may note that early in his career Dalton gave tuition for so little as a shilling an hour; that in 1792 he found London "a most surprising Place to a Stranger"; and that although he was often regarded as a gruff disciplinarian, somewhat uncouth or even morose in manner, yet in his younger days he used to write extempore verses in the diaries of his lady friends.

J. R.

\section{International River and Canal Transport}

By Brig.-General Sir Osborne Mance, assisted by J. E. Wheeler. (International Transport and Communications.) (Issued under the auspices of the Royal Institute of International Affairs.) Pp. viii+ 116. (London: Oxford University Press, 1944.) 10s. 6d. net.

TNLAND waterways have always been important lines of communication and transport, and the tendency in recent years has been to increase their use by canalization and control of flow, as their value is enhanced by hydro-electric schemes. But this new value of flowing water raises many acute problems of international control, since the most important rivers are seldom confined to one State.

Sir Osborne Mance has rendered considerable service to the river problems of to-morrow by compiling a general survey of existing international river arrangements with special reference to Europe. These arrangements will not necessarily remain, but they indicate many of the problems that will shortly have to be faced. The Rhine, Danube, Elbe and Vistula are four rivers that are hedged around with problems of this nature, each being vital to the well-being of more than one State.

It is a pity that the pamphlet gives little or no account of the depths, flow, width and lock systems of the rivers and canals, since these considerations obviously affect the problem. There are two rough sketch-maps showing the main waterways, and projected canals of central Europe.

But surely the price is high for a pamphlet of little more than a hundred pages.
The Application of Radiant Heat to Metal Finishing A Critical Survey of the 'Infra-red' Process for the Stoving of Paints and Enamels. By Dr. J. H. Nelson and H. Silman. Pp. viii+79. (London: Chapman and Hall, Ltd., 1944.) $8 s .6 d$. net.

THIS useful little book is very rightly critical of the indiscriminate use of the term 'infra-red' to describe radiant heat sources, for one cannot but be amused to see a battery of brightly incandescent lamps referred to as an 'infra-red' lamp heating plant. After a short introductory chapter on radiant heat and its advantages, the authors describe the principles of heat transfer, giving the physical laws pertaining thereto and an elementary treatment of some of the mathernatics involved. Thereafter, the study is essentially of a practical nature and includes the history of the 'infra-red' process, reflectors, plant construction and design, paint formulation and the field of application of radiant heating.

It is pointed out that while considerable progress has been made in the practice of radiant heat applied to the stoving of paints and enamels on metal surfaces, rapid developments in technique are to be expected in the very near future.

The book can be recommended to those needing guidance on the subject.

\section{Direction Finding by the Stars}

By J. B. Sidgwick. Pp. 88. (London : Faber and Faber, Ltd., 1944.) 5s. net.

VIR. SIDGWICK's little book provides much 1 useful information for those who have only a rudimentary knowledge or no knowledge of the constellations and chief stars. Starting with the Great Bear, which most people recognize, directions are given for finding and recognizing the other constellations which appear at the different seasons. The stellar bearings are easily found from a date table and a number of graphs, and the use of the table and graphs is illustrated by examples which are fully worked out. Even the novice should find no difficulty in applying these to obtain his bearings if he carries a copy of the book in his pocket. In addition to finding one's bearings, directions are given which enable the reader to determine the time by means of the sun and a number of the brighter stars. Soldiers on active service will find much useful information in the book.

M. D.

\section{Good Soil}

By S. Graham Brade-Birks. (Teach Yourself Farming Series.) Pp. 296. (Bickley : English Universities Press; Ltd., 1944.) 3s. net.

COMEWHAT more academic than are other $\checkmark$ volumes in this series, this book covers a good deal of ground in small compass and presents an invaluable introduction to soil science-though possibly the section on cartography could have been fuller. The book is especially notable as making accessible the details of Dr. Linwood L. Lee's New Jersey method of recognizing textural groups by handling the soil, for its numerous and instructive illustrations, and for its useful outline of soil mineralogy. The book pays special attention to soil texture, describes world soil groups ("the soil-pattern of the world"), and has a practical chapter on finding the best crop for every soil under English conditions.

It can be cordially recommended to biologists and non-biologists as a clear exposition of a subject about which few books exist. 